Volume 1, No. 3, September - December 2016 ISSN: 2503-4235 (p); 2503-4243 (e)

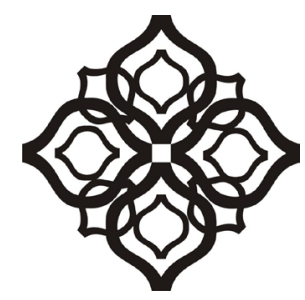

Shirkah

Journal of Economics and Business 


\section{Shirkah}

\section{Journal of Economics and Business \\ Vol. 1, No. 3, September-December 2016 \\ ISSN: 2503-4235 (p); 2503-4243 (e)}

\section{Editor in Chief}

Sri Walyoto

\section{Editorial Boards}

Abu Umar Faruq Ahmad, UBD School of Business and Economics, Brunei Darussalam

Amelia Fauzia, Asia Research Institute, National University of Singapore, Singapore

Cedomir Nestorovic, ESSEC Business School Asia Pacific, Singapore

Dwi Condro Triono, Faculty of Islamic Economics and Business, IAIN Surakarta, Indonesia

Fahmy Radhi, Faculty of Economics and Business Universitas Gadjah Mada, Yogyakarta, Indonesia

Hasan Basri, Syiah Kuala University, Aceh, Indonesia

Jaka Sriyana, Faculty of Economics, Universitas Islam Indonesia, Yogyakarta, Indonesia

Johan Fischer, Department of Social Sciences and Business Roskilde University, Denmark

Masudul Alam Choudhury, Postgraduate Program in Islamic Economics and Finance, Trisakti University, Jakarta, Indonesia and the College of Economics and Political Science (CEPS) in Sultan Qaboos University (SQU), Oman

M. Falik Isbah, School of Humanities and Social Science, University of New South Wales, Australia

M. Ishaq Bhatti, La Trobe Business School Department of Economics and Finance La Trobe University, Australia

Nunung Nurul Hidayah, Aston Business School, Aston University, Birmingham, United Kingdom

Najib Kailani, Pascasarjana, Universitas Islam Negeri (UIN) Sunan Kalijaga, Yogyakarta, Indonesia

Shaikh M Ghazanfar, Departement of Economics, University of Idaho, Russian Federation 
Managing Editors

M. Endy Saputro

M. Zainal Anwar

\section{Assistant to Editor}

Supriyanto

Shirkah Journal of Economics and Business is a peer-reviewed journal published three times a year (January-April, May-August and September-December) by Faculty of Islamic Economics and Business, Institut Agama Islam Negeri (IAIN/ State Institute for Islamic Studies) Surakarta Central Java, Indonesia. The main objective of Shirkah is to offer an academic space of exchange ideas and initiate the increase number of qualified article produced by postgraduate students, practitioners and academicians.

\section{Editorial Office}

Ruang Jurnal Shirkah

Lantai Dasar, Sayap Barat, Fakultas Ekonomi dan Bisnis Islam, IAIN Surakarta

Jln. Pandawa No. 1, Kartasura, Sukoharjo, Jawa Tengah Kode Pos. 57168

Phone (+62271) 781516 Fax: (+62271)782336

E-mail: shirkahiainsurakarta@gmail.com

Website: http://shirkah.or.id/ 



\section{Shirkah}

\section{Journal of Economics and Business}

Vol. 1, No. 3, September-December 2016

ISSN: 2503-4235 (p); 2503-4243 (e)

\section{Table of Contents}

\section{Articles}

Muhfiatun

The Effect of Sharia Monetary Policy and Financing Quality on Financial Performance in Sharia Banking

Roro Hindun

Izzul Fatchu Reza

Understanding Indonesian People Borrowing Money

from Banks and Non-Banking Institutions

M. Nur Rianto Al Arif

299

Monopoly and Ikhtikar in Islamic Economics

Trimulato

Sharia Bank Product Development through Mudhrabah Investment

Aida Nurul Hadiah

Financial Services Authority (OJK) Policy on Debt Proportion and Its Impact on the Profitability of DES Listed Companies in Indonesia

Statement of Financial Accounting Standard (PSAK)

No. 109 and Its Implementation in Several Zakat Management

Organizations in Malang, East Java 



\title{
Monopoly and Ikhtikar in Islamic Economics
}

\author{
M. Nur Rianto Al Arif \\ Faculty of Islamic Economics and Business \\ Universitas Islam Negeri (UIN) Syarif Hidayatullah Jakarta
}

\begin{abstract}
Monopoly is a form of market imperfection, which does not occur in a competitive market. Ikhtikar is a form of market distortion caused by the occurrence of engineering in the market. Monopoly, from the perspective of Islamic economics, differs from ikhtikar. There are several criteria that must be met in order for an economic action to fulfill the category of ikhtikar. In Islamic economics, it is prohibited for a producer to deliberately engineer, either by hoarding or proporting scarcity, to obtain greater profits as price becomes more expensive. In Islamic economics, a monopoly is permitted, though monopolies can not charge rent. The government must take an effective role in preventing market distortion to maximize the wellbeing of society.
\end{abstract}

Keywords: ikhtikar, monopoly, government's role

The market can be generally defined as a meeting place between sellers and buyers. In general, in the economy, the ideal market is a competitive market, where price is entirely determined by the pull of supply and demand that occurs between seller and buyer. While a competitive market is desirable in any economy, often a competitive market is not able to establish in the economy. This leads to the creation of markets that are less competitive. One form of less competitive market is a monopoly, in which there is no direct business competition. In a competitive market, a balance is formed at the intersection between seller and buyer at the equilibrium point of agreement on price and quantity between sellers and 
buyers. Both parties are on mutually beneficial conditions, and there is no injured party in these activities.

However, practically, producers sometimes engage in activities that create market distortion. In general, there are two forms of market distortion: market distortion on that demand side (known as bai najasy), and; market distortion on the supply side (known as ikhtikar) (Karim, 2002, p. 152). This paper discusses the supply side of market distortion known as ikhtikar. It asks whether ikhtikar is or is not similar to a monopoly in Islamic economics. Further, it discusses the government policy most suitable to eliminate the negative impacts of monopoly and ikhtikar.

\section{Basic Concept of Ikhtikar}

In Islamic economics, etimologically, the word ikhtikar is from the word al- $\underline{H} u k r$, where it means al-Zhulm wa 'Isâa'at al-Mu'âsyarah, or to do injustice and act arbitrarily (Fatah, 2012, p. 160). In general terminology, ikhtikar is to deliberately hold or hoard goods, especially where there is scarcity in the market, with the aim to increase price (Fatah, 2012, p. 161). In general, we can define ikhtikar as those producer activities that distort the supply side of the market to increase price and profit to the producer. Producers hoard goods restricting the supply of goods in the market which distorts the market reality.

Al-Bâjî categorized ikhtikar activities as prohibited in Islam, because it can make other products increase in worth as an impact. AlBâjî̀s statement is also supported by Ibn Qudâmah who said ikhtikar can endanger the lives of people, especially if it is food that is stockpiled. A different opinion is proposed by Al-Syîrâzî, who said that the ikhtikar law is makruh tanzir. According Al-Subkî, the law of ikhtikar is makruh tahrim. The argumentation of Al- Syîrâzî and Al-Subkî relates to the special prohibition contained in the atsar that only applies to Hakim ibn Hizam and not others (Fatah, 2012, p. 166-167). 
Al-Kâsânî said that the prohibition of ikhtikar only applies to two kinds of foods: dates and grapes. Al-Kâsânî̀s statement is supported by Ibn al-Qudâmah who suggested that the prohibition of $i k h t i k a r$ is only in relation to staple foods, since a lot of people need the goods. Besides on staple foods, ikhtikar is not prohibited. Ibn Hazm, however, has suggested that ikhtikar for all high demand food goods is erroneous and can be detrimental and also make others suffer. But, if the hoarding activities are not based on the desire for greater profits, and are not of needed goods, they cannot be categorized as prohibited ikhtikar. Al-Bâjî said that the prohibion of ikhtikar not only applies to staple foods, but also all those goods and services needed by a lot of people, because the reason of this prohibition is al-Idhrâr bi al-Nâs (needed by a lot of people) (Fatah, 2012, p. 167-168).

Ikhtikar activities can distort market mechanisms - producers can sell goods at a higher price than normal. So, producers or sellers can gain greater profit (monopolistic rent), and consumers incur consumer loss based on these activities. The impact of ikhtikar is that a lot of people suffer at the hands of a small group. In ikhtikar activities, economic agents try to manipulate the supply side, so the supply of goods reduces and the agent profits substantially. The impact of this manipulation can make the supply of particular goods rare, the implication being that the price will then be higher than normal.

Ikhtikar activities imply that if the supply of goods is smaller than the demand, the price will rise. Why does the price increase? Because the seller can pull up the price as high as they want to do, and the consumers doesn't have a bargaining position in the market.

\section{Basic Concept of Monopoly}

A monopoly is a market that has only one seller but many buyers, where the monopolist can take advantage of its control over price and 
how the profit maximizing price and quantity from what would prevail in a competitive market (Pyndick and Rubinfield, 2005, p. 339). A market is described as a monopoly if it has only one supplier. "This single firm faces the entire market demand curve [...] using its knowledge of this demand curve the monopoly makes a decision on how much to produce" (Nicholson and Snyder, 2007, p. 379).

Monopoly in general can be defined as a market where there is only one seller/producer in the market and there is no competition. But, in fact, a pure monopoly is rare. There are many sellers in the market, but if one seller has more than 50 percent of the market share we can define it as a monopoly market. The reason monopoly markets exist is that the other firms find it unprofitable or impossible to enter the market. Barriers to entry into the market are the source of all power in a monopoly. Sometimes a company doesn't have competitors because the of existence of barriers to entry to the market, so other companies can not enter the industry.

In general, there are two types of barriers to entry: technical barriers and legal barriers (Nicholson and Snyder, 2007, p. 379). There are several types of technical barriers, such as (Rahardja and Manurung, 2004, p. 183): first, the company has a special knowledge or skills, so it can produce more efficiently than its competitors or it can produce a differentiated product. Second, if the company can produce more efficiently, it will have decreased marginal and average costs. The larger the scale of production, the marginal cost will decrease and the average cost will be lower than previously. Third, the company has an ability to control resources, either natural resources, human resources or location. Fourth, the company found or has a specialized technology, so it can produce a different or more efficient product than its competitors. Otherwise, the legal barriers are caused by (Rahardja and Manurung, 2004, p. 183): first, regulation or 
privilege. In this case, the company has a monopoly right to manage some objects in the industry. Second, copyright and patent. Copyright or patent is given to individuals or companies with a special knowledge to create innovation, so it is rewarded with the patent for innovation.

There are three characteristics of a monopoly market: producer as a price maker; barriers to entry to the market; product has a differentiation if compared to other products; and fourth, the output of the producer has a greater market share (Sukirno, 2002, p. 266). There are several implications of monopoly on the welfare of a society, such as: first, loss or reduction in consumer welfare, because the production volume is smaller than the optimum production volume. This makes the company less efficient than in a competitive market. The implication of this will be a reduction in consumer welfare. Second, there will be exploitation of the consumer and the owners of production factors. Consumers are harmed because the selling price is above the equilibrium price, and the owners of production factors are harmed because the factor production price is below the market price. Third, worsening national macroeconomic conditions, because the actual output of the industry is smaller than the optimal condition. The implication of this condition will create unemployment and will havea negative impact on the economy. Fourth, inefficiencies in the industry will make it increasingly difficult for the domestic industry to compete with foreign industries (Sukirno, 2002, p. 293).

On the other side, there are some advantages to a monopoly, such as: First, the monopoly will make the monopolist pursue innovations with their products, because the rent the monopoly gains can be allocated to research and development. According to Schumpeter, it is entrepreneurs who push the growth of the economy. Second, in the case of a natural monopoly, it is less efficient for the industry if we push a competitive market, because of the limitations of the market and the larger economics 
of scale. In these conditions, if we push a competitive market a lot of small companies will be in competition but their production will be less efficient than if only one company produces all things to fulfill market demand (Hasan, 2007, p. 215).

\section{Making Distinction}

Ikhtikar is often translated as a monopoly and/ or hoarding in Islamic economics (Fatah, 2012, p. 168). Ikhtikar refers to the hoarding activities of producers or sellers. This is different to conventional economics which defines monopoly as those activities, including hoarding activies, control of resources, special knowledge, and economics of scale, among others. Thus, those who seek advantage by creating scarcity of goods are said to be a monopoly (ikhtikar) from the Islamic economic perspective. According to M.N. Siddiqi (1992), monopoly can be defined as "[...] a firm producing a product whose cross-elasticity of demand is small”. Qardhawi (1997, p. 321) defines monopoly as the activity of holding goods from being available in the market in order to raise the price. From these definitions, we can see that the objective of a monopoly is to reach maximum profit. Companies that monopolize set prices in such a way that small quantities can be sold and a greater net income obtained. Basically, Islamic economics would prefer that the market price is caused by the intersection between supply and demand in the market. Only in special cases is the monopoly market permitted. Although Qardhawi (1997, p. 322) said monopolistic activities are prohibited from the Islamic perspective, because the market monopoly is created by capitalism. M.A. Mannan (1992, p. 153) said that from the price aspect, monopoly can be categorized as an impact of a noncompetitive market. According to Mannan, price in a monopoly is higher than the competitive price and the monopoly's production is smaller the competitive ones. 
Looked at more comprehensively, ikhtikar is not always identical to monopoly or hoarding. In Islam, anyyone can do business whether they are the only seller (or producer) in market. Hoarding goods for inventory objectives is not prohibited. In Islamic economics, the prohibited activities include when the producer manipulates the supply side by hoarding or scarcity, to get a greater profit as the price becomes more expensive than before. According to Karim (2002, p. 154), activities can be defined as ikhtikar if they fulfill one of this three condition, such as: first, create scarcity by hoarding goods or imposing the entry barriers, to make the goods rare on the market. Second, by selling at a higher price than before the scarcity in the market. Third, get higher profit than before the first and second activities were undertaken.

In Islamic economics, monopolies are permitted but the monopoly's rent is prohibited. When producers hoard goods not for inventory but only to play the supply of goods in the market so that the price increases, the producer can sell after the price rises and get a larger profit from these activities, these activities are prohibited because they will harm consumers. However, if the producer hoards goods for an to inventory objective, such as the erratic weather, that can interrupt goods distribution, it is permitted. In Islamic economics, hoarding activities that have an objective to inventory and not the get greater profit is permitted (Al Arif and Amalia, 2010, p. 284). In doing so, there are differences between ikhtikar and hoarding, because in Islam hoarding goods is not wrong if we done for inventory purposes and not to disturb the market mechanism (Al Arif and Amalia, 2010, p. 243).

\section{Alternative Solutions}

In general there are several policies that can be done by the government to reduce the negative impact of monopoly, such as: first, the 
anti-trust regulation. Second, government to set up a rival company in the market to compete with the monopolist. Third, import goods to create competition for theso monopolist. Fourth, government to set up special regulations for the monopolist, such as by setting the price below the monopolist price, or set up an optimum output for the society, or impose a tax on the monopolist (Boediono, 1996, p. 131).

There are also several ways to eliminate market distortion (P3EI UII, 2008, pp. 333-341): first, the prohibition of ikhtikar; Rasulullah prohibited the ikhtikar practice of holding or hoarding goods such that the goods become rare in the market for the purpose of raising the price in the future. According to Said bin Al-Musyyab and Ma'mar bin Abdullah al-Adawi, the Prophet Muhammad said, "So sinner who do ikhtikar". The practice of ikhtikar disrupts the market mechanism, where the producer sells at the higher price than normal. The seller will gain greater profit (monopolistic rent), while the consumer will suffer from the seller's activity. So, the impact of ikhtikar will make the wider society suffer because of the activity of a minority. Government's can implement policies to eliminate hoarding, so that the price remains at market price, such as through law enforcement or price intervention. With a specified price, the hoarder can be forced to lower their prices and release goods onto the market.

Second, government must open the access to information. This is important because sometimes market distortion occurs due to limited information on either the seller's or the buyer's side. Prohibited activities caused by limited information include: talaqqi rukhban, bay najasyi, ghaban faahisy, dan bai al-hadir lil badi. Tallaqi rukhban involves the purchase of goods by intercepting sellers outside of the city, and is prohibited because often sellers don't know the current market situation - basically sellers must be aware of market information including market price and all relevant market practices. The law on these activities according to Abu Hanifah's 
perception is makrûh tahrîm, if the objective is to manipulate supply, they intervene so the sellers don't know the real price on the market. If the objective is not to manipulate the market, or not to harm the sellers and the society, the law is permitted on Shariah rules. Imam Malik said that the legally these activities are haram, because the individual has engaged in talaqqi rukbban activities and can offer the price at a higher price than the initial price. Imam Malik's opinion is supported by Imam Syafi'i, who said that it is prohibited (haram) for a person to engage in talaqqi rukhban with the motive to manipulate supply. Bay najasyi can be defined as collusion between the sellers to form a cartel to cheat consumers. Bay najasyi may also involve a situation in which a seller orders someone to make a bid on goods at a higher price to cheat the real consumers. Ghaban faahisy can be defined as the action to obscure information, so the seller can cheat the consumers to gain higher profit.

Third, government must regulate price, although price regulation is not actually popular in Islamic economic thought since it can lead to inequality in the economy. Price regulation is permitted on several conditions after consideration of the justice value. Fourth, the government must do the market intervention. In Islamic economics, government policy is meant to stabilize price to bring about market equilibrium. The root of changes in equilibrium are due to the movement of supply and demand, so price stabilization mechanisms use market intervention.

Fatah (2012, pp. 168-173) suggests there are two measures that can be done to eliminate ikhtikar: first, prevent the talaqqi rukhban; and second, to prevent bay' al-hâadhir li al-bâdî. Bay'al-hâadhir li al-bâdî is the practice of an intermediary between urban and rural people, who can take the largest profit from the impact of differentiate price. This transaction can raise the price, and so can harm others. Government intervention on these practices is the alternative solution to minimalize or even eliminate both 
practices of talaqqi rukhban or bay' al-hâadhir li al-bâdî. If the government can minimalize or even eliminate these activities, the economy will be more balanced and equitable.

\section{CONCLUSION}

Ikhtikar is not always identical with monopoly or hoarding. In Islam, everyone can do business whether there is one or many producers in the market. Hoarding is permitted for the purpose of establishing inventory. In Islamic economics, prohibitions exist where producers manipulate supply, either by hoarding goods or by creating scarcity issues, to get greater profit through higher pricing. In doing so, in Islam monopoly is permitted, but the monopoly's rent is prohibited.

Actions that can be done by the government to prevent monopoly include prohibition of ikhtikar, open access to information, price regulation, and market intervention. Governments must be aware of the root of the problem before taking action, because if the government is too reactive it can have a negative economic impact. 


\section{References}

Al Arif, M. Nur Rianto \& Euis Amalia. (2010). Teori Mikroekonomi: Suatu Perbandingan Ekonomi Islam dan Ekonomi Konvensional. Jakarta: Kencana.

Al Arif, M. Nur Rianto. (2011). Dasar-dasar Ekonomi Islam. Surakarta: Era Intermedia.

Al Syirazi, Majd al-Din Muhammad Ibn Yaqub Al Fayruz Abadi. (1398 H). Al-Qamus al Muhith juz II. Beirut: Dar-al Fikr.

Boediono. (1996). Ekonomi Mikro. Yogyakarta: BPFE Yogyakarta.

Fatah, Dede Abdul. (2012). Monopoli dalam Perspektif Ekonomi Islam, Jurnal Al-Iqtishad Fakultas Syariah dan Hukum UIN Syarif Hidayatullah Jakarta, Vol. 4, No. 2, July.

Hasan, Zubair. (2007). Introduction to Microeconomics: An Islamic Perspective, Selangor: Prentice Hall.

Karim, Adiwarman A. (2002). Ekonomi Mikro Islami, Jakarta: IIITIndonesia.

Mannan, M.A. (1992). Ekonomi Islam: Teori dan Praktik, Jakarta: Intermasa.

Nicholson, Walter \& Christopher Snyder. (2007). Theory and Application of Intermediate Microeconomics. Mason: Thomson - South Western.

P3EI UII. (2008). Ekonomi Islam, Jakarta: Rajawali Press.

Pyndick, Robert S \& Daniel L. Rubinfeld. (2005). Microeconomics. New Jersey: Pearson Education.

Rahardja, Prathama \& Mandala Manurung. (2004). Teori Ekonomi Mikro: Suatu Pengantar. Jakarta: LPFE UI.

Siddiqi, M.N. (1992). Monopoly and Monopolistic Competition in Sayid Tahir, et.al. Reading in Microeconomics: An Islamic Perspective. Selangor: Longman Malaysia. 
Sukirno, Sadono. (2002). Pengantar Teori Mikroekonomi. Jakarta: Raja Grafindo Persada.

Qardhawi, Yusuf. (1997). Peran Nilai dan Moral dalam Perekonomian Islam. Jakarta: Robbani Press. 
Vol. 1 No. 3, September - December 2016 